\title{
Etomidate in the management of hypercortisolaemia in Cushing's syndrome: a review
}

\author{
Veronica A Preda ${ }^{1,2}$, Jonathan Sen ${ }^{1}$, Niki Karavitaki ${ }^{1}$ and Ashley B Grossman ${ }^{1}$ \\ ${ }^{1}$ Department of Endocrinology, Oxford Centre for Diabetes Endocrine and Metabolism, Churchill Hospital, Oxford OX 3 7LJ, UK and ${ }^{2}$ University of Sydney, \\ Royal North Shore Hospital, St Leonards Sydney NSW 2065, Australia \\ (Correspondence should be addressed to A B Grossman; Email: ashley.grossman@ocdem.ox.ac.uk)
}

\begin{abstract}
This review addresses the practical usage of intravenous etomidate as a medical therapy in Cushing's syndrome. We reviewed the relevant literature, using search terms 'etomidate', 'Cushing's syndrome', 'adrenocortical hyperfunction', 'drug therapy' and 'hypercortisolaemia' in a series of public databases. There is a paucity of large randomised controlled trials, and data on its use rely only on small series, case study reports and international consensus guideline recommendations. Based on these, etomidate is an effective parenteral medication for the management of endogenous hypercortisolaemia, particularly in cases with significant biochemical disturbance, sepsis and other serious complications such as severe psychosis, as well as in preoperative instability. We suggest treatment protocols for the safe and effective use of etomidate in Cushing's syndrome.
\end{abstract}

European Journal of Endocrinology 167 137-143

\section{Introduction}

Endogenous Cushing's syndrome results from excessive glucocorticoid production with a failure of the normal negative feedback effect on the hypothalamo-pituitaryadrenal axis. It is traditionally divided into ACTHdependent and ACTH-independent Cushing's syndrome. In the majority of cases, it is caused by an adenoma in the pituitary gland secreting ACTH hormone (Cushing's disease), more rarely due to ACTH secretion by an ectopic source; of the adrenal causes, these are usually adrenal adenomas or carcinomas, with a small group due to bilateral adrenal hyperplasia (1). Detailed biochemical and imaging paradigms have been designed to diagnose the presence of Cushing's syndrome and to differentially identify ACTH dependence or independence and the precise pathology. If untreated, there is significant morbidity and potential mortality related to life-threatening infections, diabetes mellitus, hypertension and an increased risk associated with surgery.

For Cushing's disease, surgical removal of the pituitary tumour is the usual first-line therapy, with radiotherapy reserved for surgical failure, or occasionally bilateral adrenalectomy. Laparoscopic adrenalectomy is highly effective in the ectopic ACTH syndrome (2) and occasionally in Cushing's disease, but its use may cause unnecessary or inappropriate delay. Patients should be referred in a timely fashion to a facility where appropriate laparoscopic surgical expertise exists. Earlier planned surgical intervention may be a means of resolving hypercortisolaemia, although even with modern techniques preoperative lowering of the hypercortisolaemia may be important. However, there is still a widespread requirement for medical therapy. In the first instance, severe biochemical disturbance (e.g. hypokalaemia), immunosuppression and/or mental instability may need immediate and life-saving cortisol-lowering therapy, while following radiotherapy, medical therapy may be necessary whilst waiting for the treatment to become effective. In some cases, surgical cure is impossible and management with drugs able to lower cortisol may be needed in the short term or even in the long term $(1,3)$.

The medical therapy of hypercortisolaemia in Cushing's syndrome is predominantly based on the inhibition of adrenal steroidogenesis at one or more enzymatic sites, or alternatively by antagonism of the glucocorticoid receptor or the suppression of ACTH. Oral therapy with ketoconazole and metyrapone are the most frequent steroidogenic enzyme inhibitors currently in use, but these agents are not always well tolerated. Ketoconazole is associated with disturbances of hepatic function, while metyrapone may cause nausea independent of its cortisol-lowering activity and thus large doses cannot be taken, and accumulation of androgenic precursors may be problematic (4). Occasional patients may need to be treated with the 
glucocorticoid receptor antagonist mifepristone, or a minority of patients with Cushing's disease may have their excess cortisol normalised with pasireotide. Subcutaneous pasireotide is a new targeted pituitary therapy, a somatostatin analogue that binds to the somatostatin receptors and with particular high affinity for somatostatin receptor subtype 5. It normalised glucocorticoid output in around $20-25 \%$ of patients in a recent study, although its major side effects, hyperglycaemia and diabetes mellitus, occurred in $73 \%$ of patients (5). However, in patients with severe hypercortisolaemia unable or unwilling to tolerate oral therapy, bilateral adrenalectomy may be necessary $(4,6)$. Surgical risk may be significantly reduced if cortisol concentrations are normalised preoperatively (12). Thus, the use of a parenteral hypocortisolaemic agent may be essential before or during adrenalectomy in patients with severe life-threatening hypercortisolaemia. Intravenous etomidate has a role in this setting.

\section{Etomidate}

Etomidate and ketoconazole are members of the imidazole family. Etomidate is a carboxylated imidazole synthesised in 1964 and introduced into use in 1972. It was developed as an intravenous hypnotic nonbarbiturate induction anaesthetic agent (7) and has a plasma half-life of 3-5 h. The anaesthetic effects of etomidate in the CNS are thought to be via activation of $\gamma$-aminobutyric acid type A receptors (8). Etomidate was popular for its reputation in cardiovascular stability, with little change in blood pressure and heart rate, as well as lack of histamine release, but was noted to result in increased mortality in critically unwell patients (9): this was later shown to be associated with low serum cortisol levels resulting in hypoadrenalism (10). However, a recent meta-analysis was unable to conclude that there was an increase in mortality in patients who were given etomidate as a single dose in rapid sequence induction anaesthesia (11): the debate on the usage of etomidate in the anaesthetic literature continues. Etomidate inhibits the mitochondrial cytochrome p450-dependent adrenal enzyme $11 \beta$ hydroxylase that catalyses the production of cortisol from deoxycortisol and is 95\% homologous to the aldolase enzyme in the pathway to aldosterone synthesis, lowering serum cortisol levels within $12 \mathrm{~h}$ $(12,13,14,15)$. On this basis, it was suggested that etomidate could be a useful therapy for severe hypercortisolaemia in patients intolerant of or unable to take oral medication. At higher doses, etomidate blocks side chain cleavage enzyme. More recent work has not only shown etomidate to potently block $11 \beta$ hydroxylase and side chain cleavage enzyme but also aldosterone synthase and may have anti-proliferative effects on adrenal cortical cells $(16,17)$. Therefore, etomidate also has therapeutic relevance for aldosterone blockade and anti-tumorigenesis for metastatic adrenocortical tumours. Post-translational work is underway to manufacture synthetic similar compounds to etomidate with high potency inhibition of the steroid pathway and weak interactions with $\gamma$-aminobutyric acid type A receptors in order to harness its therapeutic benefits in treating hypercortisolism and to minimise its anaesthetic properties (8).

\section{Methodology}

Publications were identified by means of a systematic literature search in the period of January 1946 to April 2012 using the Medline, EMBASE, Cochrane and Scopus databases, limited to English language publications. Other studies were identified from the bibliography of short-listed articles. The search criteria used in the Medical Subject Headings (MeSH) are as follows: 'etomidate, Cushing's syndrome, hypercortisolaemia, adrenocortical hyperfunction and drug therapy'. Supplementary references for guidelines were identified via Google Scholar. An initial review of all titles and abstracts was performed for relevance. If deemed appropriate for further review, access to the full article was obtained. Eighteen key clinical references, most of which were case reports for the primary therapeutic use of etomidate in hypercortisolism, were identified.

\section{Clinical experience}

Gärtner et al. (18) used the therapeutic effect of sedative doses of $15-30 \mathrm{mg} / \mathrm{h}$ etomidate in a 53-year male patient with an ectopic ACTH-producing tumour and untreatable psychosis. They were the first to demonstrate the beneficial effect of etomidate on hypercortisolism for clinical benefit over a 14-day infusion with improvement in the patient's hypertension and hypokalaemia associated with a fall in cortisol levels. Engelhardt et al. (19) demonstrated the cortisollowering effect of non-sedating etomidate in three normal volunteers in 1986. Allolio et al. (20) in 1988 were the first to demonstrate that a 32-h infusion of low-dose $2.5 \mathrm{mg} / \mathrm{h}$ ethyl alcohol etomidate could inhibit cortisol secretion in patients with hypercortisolaemia within 11-24 h. They were able to demonstrate that low plasma doses achieved adrenocortical blockade distinct from the sedative potential used in anaesthesia, which was typically at a dose of an initial induction anaesthetic bolus of $0.03 \mathrm{mg} / \mathrm{kg}$ followed by a continuous infusion of $0.3 \mathrm{mg} / \mathrm{kg}$ per $\mathrm{h}$ to maintain sedation. (For the average $70 \mathrm{~kg}$ subject, this equates to a bolus dose of $2.1 \mathrm{mg}$ followed by $21 \mathrm{mg} / \mathrm{h}$ etomidate infusion.) At the dose of $2.5 \mathrm{mg} / \mathrm{h}$, there was suppression of excess cortisol within the reference range; however, the cortisol response to exogenous ACTH of $250 \mu \mathrm{g}$ was reduced but not completely blocked, in contrast to the 


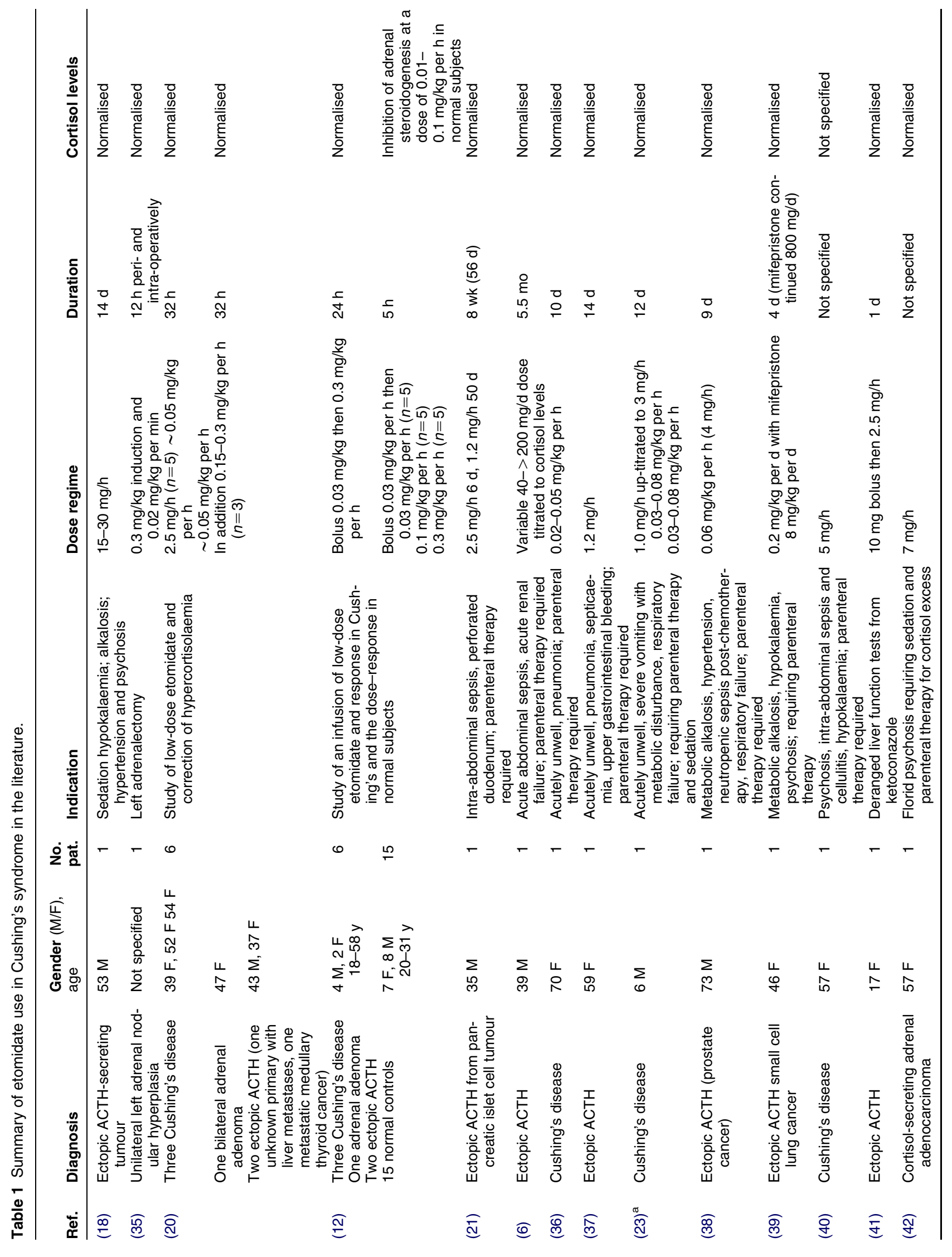




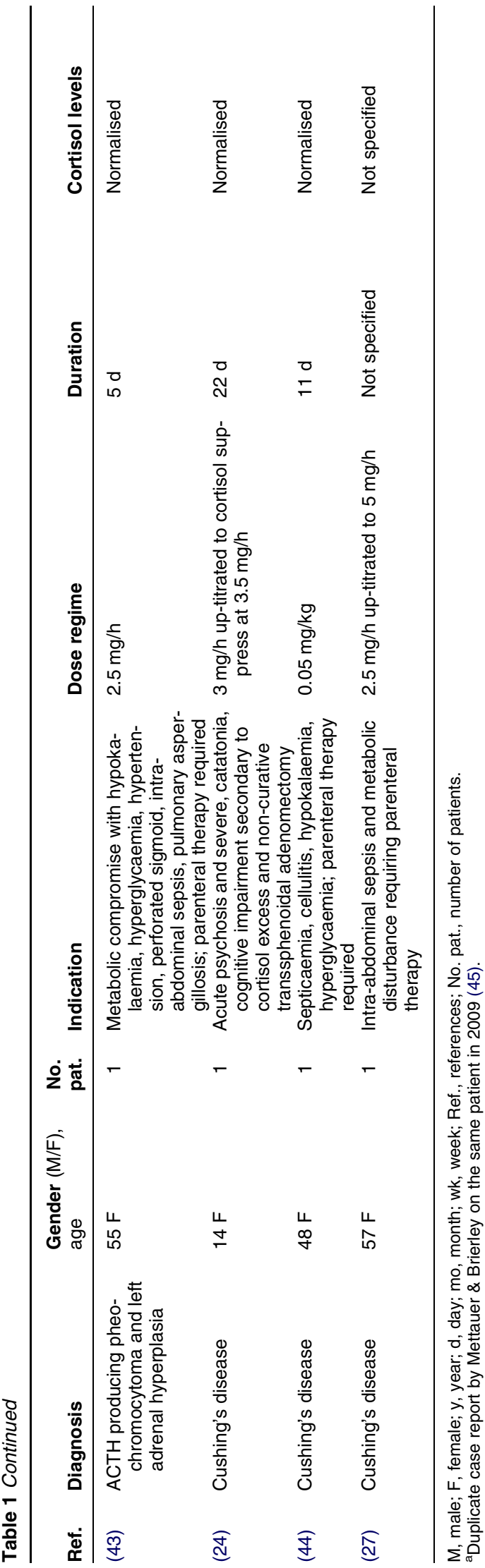

significantly higher anaesthetic dosages showing complete blockade.

Given the wide dosing range between adrenostatic and anaesthetic effects, further work by Schulte et al. in 1990 reported the differential effects. They published the effect of etomidate on cortisol levels after an initial bolus of $0.03 \mathrm{mg} / \mathrm{kg}$ for all patients $(n=21)$ followed by an infusion in 15 normal volunteers for $5 \mathrm{~h}$ and six patients with Cushing's syndrome over $24 \mathrm{~h}$ of varying doses in the normal group of $0.03,0.1$ and $0.3 \mathrm{mg} / \mathrm{kg}$ per $\mathrm{h}$, and $0.3 \mathrm{mg} / \mathrm{kg}$ per $\mathrm{h}$ in the Cushing's group, elegantly separating the dose-related adrenostatic and anaesthetic effects (12). They concluded that etomidate at a dose of $0.1 \mathrm{mg} / \mathrm{kg}$ per $\mathrm{h}$ or lower was effective for the control of severe hypercortisolaemia. Further case reports have demonstrated the long-term (months) use of both ethyl alcohol etomidate and propylene glycol etomidate $(6,21)$. Multiple case reports have used parenteral etomidate for shorter durations in the setting of required parenteral therapy in both adults and children. This has been for Cushing's-induced psychosis, severe metabolic disturbances that need concurrent mechanical ventilation, normalisation of hypercortisolaemia before bilateral adrenalectomy, patients failing usual per oral medical therapy, subjects with increased surgical risk and in those not appropriate for surgery due to intra-abdominal sepsis (Table 1).

In anaesthesia, induction bolus doses of etomidate are typically $0.2 \mathrm{mg} / \mathrm{kg}-0.4 \mathrm{mg} / \mathrm{kg}$ per $\mathrm{h}$ with resultant apnoea and hypnosis within 10-15 s of the onset of the infusion (22). In the original study by Allolio et al. (20) using etomidate for cortisol suppression, tiredness was reported in some patients at doses of $0.3 \mathrm{mg} / \mathrm{kg}$ per $\mathrm{h}$. Doses of $0.04-0.05 \mathrm{mg} / \mathrm{kg}$ per $\mathrm{h}$ were found to adequately inhibit, but not sedate, and this was further clarified in dose-response studies by Schulte et al. (12) demonstrating inhibition of adrenal steroidogenesis at $0.01-0.1 \mathrm{mg} / \mathrm{kg}$ per $\mathrm{h}(20)$. Several publications that followed report sub-hypnotic i.v. $2.5-3.5 \mathrm{mg} / \mathrm{h}$ doses of etomidate completely inhibiting endogenous cortisol production $(21,23,24)$. In the case reports where patients were rendered hypoadrenal, this was demonstrated by serum cortisol levels $<100 \mathrm{nmol} / \mathrm{l}$ and glucocorticoid replacement therapy was provided by a continuous i.v. hydrocortisone infusion, using a dose that guaranteed serum cortisol level of around $500 \mathrm{nmol} / \mathrm{l}$. This was considered to be appropriate as a 'physiological stress' in an intensive care setting $(21,25)$.

Dosages of etomidate need to be individualised to the clinical scenario. A recent case presentation of a severely ill 57-year-old female patient with ACTHdependent Cushing's syndrome from a pituitary microadenoma, complicated by bowel perforation, who was not controlled by the initial etomidate dose of $2.5 \mathrm{mg} / \mathrm{h}$ or the up-titrated dose of $5 \mathrm{mg} / \mathrm{h}$, may have required a further up-titration of dose. This requires measurement of the cortisol levels and also the cortisol response to exogenous ACTH to demonstrate complete or partial 
blockade. In order to demonstrate 'escape', an increase in endogenous ACTH and cortisol secretion must occur with exogenous ACTH $(20,26)$. There is no true resistance to etomidate with this escape phenomenon. In the clinical situation of increased ACTH secretion, in Cushing's disease, this most likely increases the availability of steroidogenic enzymes, shifting the balance to free enzyme available for steroid synthesis: an increase in etomidate should therefore block the higher concentration of steroidogenic enzymes. However, at these higher doses, sedation is induced. In the alternative scenario of patients with adrenal Cushing's syndrome, or most patients with the ectopic ACTH syndrome, where there is no compensatory ACTH increase, they may be particularly sensitive to the blocking effect of etomidate resulting in adrenal insufficiency. It is a common feature of all enzyme inhibitors that there is a higher sensitivity of ACTH-independent Cushing's syndrome to adrenal enzyme blockade. Thus, we stress the importance of a monitored environment such as a high dependency ward, with medical staff equipped with the capacity to support the airway if sedation does occur, and to monitor patients and their cortisol levels closely to rapidly respond to hypoadrenalism. Dosages of etomidate therefore require individualisation, and lack of dose titration is a more likely explanation for failed adequate therapy in the literature with etomidate for Cushing's disease (27).

Etomidate is highly plasma bound and is metabolised to inactive metabolites by hepatic and plasma esterases. The metabolites are inactive and excreted in the urine and to a lesser degree in bile. Elderly or ill patients require reduced doses as there is decreased protein binding and reduced renal clearance (8). Etomidate is unstable in water at physiological $\mathrm{pH}$, and to increase solubility, it is most commonly available in the UK as a clear colourless liquid formulated as $0.2 \%$ in $35 \%$ propylene glycol. It is also available as a lipid emulsion, and formulations in cyclodextrins, starch-derived molecules that can form reversible inclusion complexes with lipophilic drugs, have also been developed (28). Propylene glycol is a solvent used in many topical, oral and injectable medications. A side effect of the most commonly available propylene glycol preparation vehicle is thrombophlebitis and pain on injection in $25 \%$ of patients (29), which is considerably reduced with the lipid preparation (30). Haemolysis has been recorded due to the high osmolality of the preparation of etomidate in propylene glycol compared with the lipid formulation (31). Propylene glycol is associated with nephrotoxicity due to proximal renal tubular injury and lactic acidosis at high doses (32). Krakoff et al. reported the prolonged use of etomidate for over 5 months without haemolysis, worsening nephrotoxicity or metabolic acidosis, and many of the case reports for the treatment of hypercortisolaemia do not comment on this being a significant issue. The World Health Organization recommends a daily maximal dose of $25 \mathrm{mg} / \mathrm{kg}$ of propylene glycol to decrease the possibility of toxicity (6). Care with dosing to ensure appropriate margins of safety is therefore important. Ideally, the lipid formulation would be the preferred formulation as it avoids the propylene glycol vehicle side effects. Finally, other potential adverse effects from the etomidate include myoclonus, nausea, vomiting and dystonic reactions in up to one-third of patients at anaesthetic dosages (33).

\section{Clinical recommendations}

A consensus statement on the treatment of ACTHdependent Cushing's syndrome comprising leading endocrinologists, other clinicians and neurosurgeons with expertise in the management of ACTH-dependent Cushing's syndrome was published in 2008 (1). This included a recommendation for the use of etomidate where rapid control of cortisol levels is required and oral therapy is problematic. In practice, etomidate is a safe and effective drug for the control of hypercortisolaemia in a patient requiring parenteral therapy. A highly co-ordinated multidisciplinary approach is, however, necessary for the management of unwell hypercortisolaemic patients, as this group has complex problems beyond the daily ward scope of medical and nursing staff. The clinical setting of an intensive care or high dependency unit is therefore recommended for close

Table 2 Treatment of hypercortisolism with etomidate recommendations.

\begin{tabular}{|c|c|c|c|c|}
\hline $\begin{array}{l}\text { Etomidate infusion } \\
\text { rate options }\end{array}$ & Blockade & Target cortisol level & $\begin{array}{l}\text { Biochemical } \\
\text { monitoring }\end{array}$ & Other \\
\hline $\begin{array}{c}0.04-0.05 \mathrm{~m} / \mathrm{kg} \mathrm{per} \\
\mathrm{h}=2.5-3.0 \mathrm{mg} / \mathrm{h}\end{array}$ & Partial & $\begin{array}{l}\text { Titrate to serum cortisol } \\
500-800 \mathrm{nmol} / \mathrm{l} \text { in } \\
\text { physiologically stressed } \\
\text { patient, } 150-300 \mathrm{nmol} / \mathrm{l} \text { in } \\
\text { non-physiologically } \\
\text { stressed patient }\end{array}$ & Cortisol level & $\begin{array}{l}\text { Sedation scoring initially } \\
\text { every } 2 \mathrm{~h} \text { then every } 12 \mathrm{~h} \\
\text { after first } 24 \mathrm{~h}\end{array}$ \\
\hline $0.5-1.0 \mathrm{mg} / \mathrm{h}$ & $\begin{array}{l}\text { Complete (will } \\
\text { need steroid } \\
\text { replacement) }\end{array}$ & $<150 \mathrm{nmol} / \mathrm{l}$ & Potassium level & $\begin{array}{l}\text { Sedation scoring initially } \\
\quad \text { every } 2 \mathrm{~h} \text { then every } 12 \mathrm{~h}\end{array}$ \\
\hline
\end{tabular}


patient and biochemical testing monitoring, particularly for serum cortisol and potassium levels and the documentation of the level of sedation.

Intravenous low-dose etomidate infusion rates for the treatment of hypercortisolaemia are $0.04-0.05 \mathrm{mg} / \mathrm{kg}$ per $\mathrm{h}$, thus equating to $\sim 2.5-3 \mathrm{mg} / \mathrm{h}$ with dose titration according to serum cortisol. Based on etomidate's pharmacokinetics, cortisol levels fall within 12-24 h. Frequent monitoring is necessary for serum cortisol levels to achieve either complete or partial blockade and to prevent hypoadrenalism. Intravenous hydrocortisone at $0.5-1 \mathrm{mg} / \mathrm{h}$ is required if complete rather than partial blockade is desired ('block and replace') and is often more convenient than frequently altering the etomidate infusion rate to achieve only partial blockade. Nevertheless, both approaches may be considered as valid. The target serum cortisol based on mean 24-h cortisol levels in patients in an intensive care setting is $500-800 \mathrm{nmol} / \mathrm{l}$ (25). This is higher than the non-physiologically stressed individual in a non-acute setting in which the accepted range for serum cortisol is $150-300 \mathrm{nmol} / \mathrm{l}$ (34). Clearly, the level aimed for depends on the clinical context and will need to be carefully considered in special situations, such as severe sepsis. Our own approach is always to take into account the serum cortisol level that would be expected in a given clinical context in the absence of Cushing's syndrome (Table 2).

Other considerations when using etomidate include access and minimisation of thrombophlebitis with the transport vehicle. Given the monitored clinical setting, particularly where patients are generally unwell and they are likely to require multiple i.v. therapies, central venous access is most appropriate when using the propylene glycol preparation. Although etomidate is degraded into inactive metabolites by hepatic enzymes and plasma esterases, it rarely causes issues with significant hepatotoxicity. Etomidate has a plasma half-life of 3-5 h. Dose adjustment in renal failure should be made, as most etomidate is usually protein bound, and in the context of renal failure, there is therefore an increase in the free etomidate (6). Etomidate is a safe drug, with a 30-fold difference between the lethal and effective dose at the higher dosages used to induce anaesthesia. In the elderly and very ill patients, decreased dosing needs to occur due to decreased protein binding and renal clearance (8).

\section{Conclusions}

Additionally, etomidate is a very useful addition to the therapeutic armamentarium for the control of Cushing's syndrome, particularly in the acute care hospital setting, where oral therapy is either not tolerated or inappropriate. In the outpatient endocrinology setting for patients with severe hypercortisolism, albeit not acute, requiring therapy, but unable to tolerate a large pill burden, there might be a role for etomidate.
However, it should be used in an intensive care setting and the doses used need to be carefully assessed, usually in the region of $0.04-0.05 \mathrm{mg} / \mathrm{kg}$ per $\mathrm{h}$, which equates to $2.5-3 \mathrm{mg} / \mathrm{h}$ on average. Close serum cortisol monitoring in a high dependency, intensive care setting is essential to ensure that adrenal insufficiency does not occur. Nevertheless, its use can be life-saving where all other treatments have failed.

\section{Declaration of interest}

The authors declare that there is no conflict of interest that could be perceived as prejudicing the impartiality of the review reported.

\section{Funding}

This review did not receive any specific grant from any funding agency in the public, commercial or not-for-profit sector.

\section{References}

1 Biller BM, Grossman AB, Stewart PM, Melmed S, Bertagna X, Bertherat J, Buchfelder M, Colao A, Hermus AR, Hofland LJ, Klibanski A, Lacroix A, Lindsay JR, Newell-Price J, Nieman LK, Petersenn S, Sonino N, Stalla GK, Swearingen B, Vance ML, Wass JA \& Boscaro M. Treatment of adrenocorticotropindependent Cushing's syndrome: a consensus statement. Journal of Clinical Endocrinology and Metabolism 200893 2454-2462. (doi:10.1210/jc.2007-2734)

2 Henry JF, Defechereux T, Raffaelli M, Lubrano D \& Gramatica L. Complications of laparoscopic adrenalectomy: results of 169 consecutive procedures. World Journal of Surgery 200024 1342-1346. (doi:10.1007/s002680010222)

3 Morris D \& Grossman AB. The medical management of Cushing's syndrome. Annals of the New York Academy of Sciences 2002970 119-133. (doi:10.1111/j.1749-6632.2002.tb04418.x)

4 Feelders RA. Hofland LJ \& de Herder WW. Medical treatment of Cushing's syndrome: adrenal-blocking drugs and ketaconazole. Neuroendocrinology 201092 (Suppl 1) 111-115. (doi:10.1159/ 000314292)

5 Colao A, Petersenn S, Newell-Price J, Findling JW, Gu F, Maldonado M, Schoenherr U, Mills D, Roberto Salgado L \& Biller BMK. A 12-month phase 3 study of pasireotide in Cushing's disease. New England Journal of Medicine 2012366 914-924. (doi:10.1056/NEJMoa1105743)

6 Krakoff J, Koch CA, Calis KA, Alexander RH \& Nieman LK. Use of a parenteral propylene glycol-containing etomidate preparation for the long-term management of ectopic Cushing's syndrome. Journal of Clinical Endocrinology and Metabolism 2001 86 4104-4108. (doi:10.1210/jc.86.9.4104)

7 Gooding JM \& Corssen G. Etomidate. Anesthesia and Analgesia 1976 55 286-289.

8 Forman SA. Clinical and molecular pharmacology of etomidate. Anesthesiology 2011114 695-707. (doi:10.1097/ALN.0b013e 3181ff72b5)

9 Ledingham IM \& Watt I. Influence of sedation on mortality in critically ill multiple trauma patients. Lancet $1983 \mathbf{3 2 1} 1270$. (doi:10.1016/S0140-6736(83)92712-5)

10 Watt I \& Ledingham IM. Mortality amongst multiple trauma patients admitted to an intensive therapy unit. Anaesthesia 1984 39 973-981. (doi:10.1111/j.1365-2044.1984.tb08885.x)

11 Hohl CM, Kelly-Smith CH, Yeung TC, Sweet DD, Doyle-Waters MM \& Schulzer M. The effect of a bolus dose of etomidate on cortisol levels, mortality, and health services utilization: a systematic review. Annals of Emergency Medicine 201056 105-113 e5. (doi:10.1016/j.annemergmed.2010.01.030) 
12 Schulte HM, Benker G, Reinwein D, Sippell WG \& Allolio B. Infusion of low dose etomidate: correction of hypercortisolemia in patients with Cushing's syndrome and dose-response relationship in normal subjects. Journal of Clinical Endocrinology and Metabolism 199070 1426-1430. (doi:10.1210/jcem-70-5-1426)

13 Duthie DJR, Fraser R \& Nimmo WS. Effect of induction of anaesthesia with etomidate on corticosteroid synthesis in man. British Journal of Anaesthesia 198557 156-159. (doi:10.1093/bja/57.2.156)

14 Wagner RL, White PF, Kan PB, Rosenthal MH \& Feldman D. Inhibition of adrenal steroidogenesis by the anesthetic etomidate. New England Journal of Medicine 1984310 1415-1421. (doi:10. 1056/NEJM198405313102202)

15 Mornet E, Dupont J, Vitek A \& White PC. Characterization of two genes encoding human steroid 11 beta-hydroxylase (P-450(11) beta). Journal of Biological Chemistry 1989264 20961-20967.

16 Hahner S, Stürmer A, Fassnacht M, Hartmann RW, Schewe K, Cochran S, Zink M, Schirbel A \& Allolio B. Etomidate unmasks intraadrenal regulation of steroidogenesis and proliferation in adrenal cortical cell lines. Hormone and Metabolic Research 2010 42 528-534. (doi:10.1055/s-0030-1249629)

17 Fassnacht M, Hahner S, Beuschlein F, Klink A, Reincke M \& Allolio B. New mechanisms of adrenostatic compounds in a human adrenocortical cancer cell line. European Journal of Clinical Investigation 200030 (Suppl 3) 76-82. (doi:10.1046/j.13652362.2000.0300s3076.x)

18 Gärtner R, Albrecht M \& Müller OA. Effect of etomidate on hypercortisolism due to ectopic ACTH production. Lancet 1986 1 275. (doi:10.1016/S0140-6736(86)90811-1)

19 Engelhardt D, Suttmann H, Jacob K \& Dörr HG. Influence of low-dose etomidate on adrenal and gonadal steroid hormone secretion in normal men. Acta Endocrinologica 1986113 (Suppl 1) S21-S22.

20 Allolio B, Schulte HM, Kaulen D, Reincke M, Jaursch-Hancke C \& Winkelmann W. Nonhypnotic low-dose etomidate for rapid correction of hypercortisolaemia in Cushing's syndrome. Klinische Wochenschrift 198866 361-364. (doi:10.1007/BF01735795)

21 Drake WM, Perry LA, Hinds CJ, Lowe DG, Reznek RH \& Besser GM. Emergency and prolonged use of intravenous etomidate to control hypercortisolemia in a patient with Cushing's syndrome and peritonitis. Journal of Clinical Endocrinology and Metabolism 1998 83 3542-3544. (doi:10.1210/jc.83.10.3542)

22 Heyn J, Geiger C, Hinske CL, Briegel J \& Weis F. Medical suppression of hypercortisolemia in Cushing's syndrome with particular consideration of etomidate. Pituitary $2012 \quad 15 \quad 117-125$ (doi:10.1007/s11102-011-0314-3)

23 Greening JE, Brain CE, Perry LA, Mushtaq I, Sales Marques J, Grossman $\mathrm{AB} \&$ \& Savage MO. Efficient short-term control of hypercortisolaemia by low-dose etomidate in severe paediatric Cushing's disease. Hormone Research 200564 140-143. (doi:10. 1159/000088587)

24 Chan LF, Vaidya M, Westphal B, Allgrove J, Martin L, Afshar F, Hindmarsh PC, Savage MO, Grossman AB \& Storr HL. Use of intravenous etomidate to control acute psychosis induced by the hypercortisolaemia in severe paediatric Cushing's disease. Hormone Research in Paediatrics 201175 441-446. (doi:10.1159/ 000324419)

25 Ross R, Miell JP, Holly JM, Maheshwari H, Norman M, Abdulla AF \& Buchanan CR. Levels of GH binding activity, IGFBP-1, insulin, blood glucose and cortisol in intensive care patients. Clinical Endocrinology 199135 361-367. (doi:10.1111/j.1365-2265.1991.tb03549.x)

26 Mullan KR \& Atkinson AB. Endocrine clinical update: where are we in the therapeutic management of pituitary-dependent hypercortisolism? Clinical Endocrinology 200868 327-337. (doi:10.1111/j.1365-2265.2007.03028)

27 Lim CT et al. A severely ill patient with Cushing's disease that escaped medical control. In Fourteenth Clinicopathological Conference on Pituitary Disease. London, 2012.

28 Doenicke A, Roizen MF, Nebauer AE, Kugler A, Hoernecke R \& Beger-Hintzen H. A comparison of two formulations for etomidate, 2-hydroxypropyl-beta-cyclodextrin (HPCD) and propylene glycol. Anesthesia and Analgesia 199479 933-939. (doi:10.1213/ 00000539-199411000-00020)
29 Zacharias M, Clarke RS, Dundee JW \& Johnston SB. Venous sequelae following etomidate. British Journal of Anaesthesia 1979 51 779-783. (doi:10.1093/bja/51.8.779)

30 Nyman Y, Von Hofsten K, Palm C, Eksborg S \& Lönnqvist PA. Etomidate-Lipuro is associated with considerably less injection pain in children compared with propofol with added lidocaine. British Journal of Anaesthesia 200697 536-539. (doi:10.1093/bja/ael187)

31 Doenicke A, Roizen MF, Hoernecke R, Mayer M, Ostwald P \& Foss J. Haemolysis after etomidate: comparison of propylene glycol and lipid formulations. British Journal of Anaesthesia $1997 \mathbf{7 9}$ 386-388. (doi:10.1093/bja/79.3.386)

32 Yorgin PD, Theodorou AA, Al-Uzri A, Davenport K, BoyerHassen LV \& Johnson MI. Propylene glycol-induced proximal renal tubular cell injury. American Journal of Kidney Diseases 1997 30 134-139. (doi:10.1016/S0272-6386(97)90577-1)

33 Morris C \& McAllister C. Etomidate for emergency anaesthesia; mad, bad and dangerous to know? Anaesthesia $200560737-740$. (doi:10.1111/j.1365-2044.2005.04325.x)

34 Trainer PJ, Eastment C, Grossman AB, Wheeler MJ, Perry L \& Besser GM. The relationship between cortisol production rate and serial serum Cortisol estimation in patients on medical therapy for Cushing's syndrome. Clinical Endocrinology 199339 441-443. (doi:10.1111/j.1365-2265.1993.tb02391.x)

35 Costa J, Ramos D, Massada S, Carvalho D \& Pignatelli D. Etomidate and Cushing's syndrome. Anaesthesia 198641 211-212. (doi:10. 1111/j.1365-2044.1986.tb13187.x)

36 Herrmann BL, Mitchell A, Saller B, Stolke D, Forsting M \& Frilling A. Transsphenoidale hypophysektomie bei einer patientin mit einem ACTH-produzierenden hypophysenadenom und einer "empty Sella" nach vorbehandlung mit etomidat. Deutsche Medizinische Wochenschrift 2001126 232-234. (doi:10.1055/s-2001-11477)

37 Hay CJ, Eddleston JM \& Wu FCW. The use of intravenous etomidate infusion in the acute control of life-threatening hypercortisolaemia in a case of ACTH-dependent Cushing's syndrome. Endocrine Abstracts 2003542.

38 Johnson TN \& Canada TW. Etomidate use for Cushing's syndrome caused by an ectopic adrenocorticotropic hormone-producing tumor. Annals of Pharmacotherapy 200741 350-353. (doi:10. 1345/aph.1H365)

39 Bilgin YM, van der Wiel HE, Fischer HR \& De Herder WW. Treatment of severe psychosis due to ectopic Cushing's syndrome. Journal of Endocrinological Investigation 200730 776-779.

40 Fountain AEC, McGowan BMC, Chaudhuri O, Saha S, Field BCT, Dhillo W, Todd JF, Goldstone AP, Martin NM, Meeran K \& Tan T. Challenges in the management of Cushing's syndrome in the severely ill patient. Endocrine Abstracts 2008189.

41 Dabbagh A, Sa'adat N \& Heidari Z. Etomidate infusion in the critical care setting for suppressing the acute phase of Cushing's syndrome. Anesthesia and Analgesia 2009108 238-239. (doi:10. 1213/ane.0b013e318187ed37)

42 Brahma A, Karaczun M \& Dhatariya K. Emergency use of etomidate in acute steroid psychosis for an adrenal cancer causing Cushing's syndrome. Endocrine Abstracts 201022184.

43 Lutgers HL, Vergragt J, Dong PV, de Vries J, Dullaart RP, van den Berg G \& Ligtenberg JJ. Severe hypercortisolism: a medical emergency requiring urgent intervention. Critical Care Medicine 201038 1598-1601. (doi:10.1097/CCM.0b013e3181e47b7a)

44 Stinnett A, Neill K \& Jones K. 104: Case report: use of etomidate infusion for acute treatment of Cushing's syndrome. Critical Care Medicine 201139 20. (doi:10.1097/01.ccm.0000408627. 24229.88)

45 Mettauer N \& Brierley J. A novel use of etomidate for intentional adrenal suppression to control severe hypercortisolemia in childhood. Pediatric Critical Care Medicine 200910 e37-e40. (doi:10.1097/PCC.0b013e318198b096)

Received 28 March 2012

Revised version received 1 May 2012

Accepted 10 May 2012 